\title{
Jälle üks kass
}

\section{Ülo Siimets}

Pärast kassi nimega Kiisu-Liisu, kes hiljem osutus Liisu asemel hoopis Kiisu-Miisuks, ei olnud meil tükk aega ühtegi kodulooma. Uskusin, et ühelegi koduloomale ei ole vaja nii ränka katsumust, kui sai osaks viimasele kassile. Arvasin, et ega neid koduloomi saagi meil olema, enne kui ma kuhugi maavaikusesse pensionipõlve pidama jään. Kuid jumala mõtted ja teod on ettearvamatud.

Minu tütar abiellus ja kolis elama oma mehe Andrese juurde Vallikraavi tänavasse. See oli endine von Oettingenide maja. Ma ei saa siin jätta juhust kasutamata, et meenutada lugejale seda kuulsat suguvõsa.

Tartu Ülikooli tuli Visusti mõisast õppima kuus venda von Oettigeni: vanuse järgi August, Georg, Nikolai, Aleksander, Eduard ja Arthur. Kõik nad kuulusid korporatsiooni Livonia. Kõik nad täiendasid oma erialaseid teadmisi välismaal. Vanim vendadest valiti 1857. aastal Liivimaa maamarssaliks ja nimetati 1862. aastal Liivimaa kuberneriks, millisel kohal ta püsis kuni 1868. aastani. 1880. aastate lõpul sai temast Riia linnapea. Samal ajal juhtis teine vend Georg ülikoolilinna Tartut. Kolmas vend Nikolai õppis majandust ja tegeles pangandusega, hiljem oli aga Tartu maakohtunik ja Liivimaa maamarssal. Neljas vend Alexander õppis teoloogiat ning temast sai Tartu Ülikooli süstemaatilise teoloogia professor ja usuteaduskonna dekaan. Viies vend Eduard juhtis Liivimaa rüütelkonna funktsionärina kubermangu kiriku- ja hariduselu. Kuues vend Arthur sai 31-aastaselt Tartu Ülikooli füüsikaprofessoriks, kujunedes võimekaks teadlaseks (Otten 1908).

Vennad ehitasid endale Vallikraavi ja Tiigi tänava vahele majad nii, et nende krundid puutusid kokku ja moodustasid ühise territooriumi. Ühele krundile ehitati ka trepid, et oleks võimalik paremini oru nõlvakul asuvate majade juurest alla Vallikraavi tänavas oleva maja juurde ja jälle üles pääseda. 
Ühel päeval sain teada, et Andrese tütar Juudit on võtnud endale kassi. Tegelikult võib siin kohe vaidlema hakata, kes kelle endale võttis. Märtsi keskel, mitte just kõige soojemal kevadõhtul, tuli see kass Juuditi korteri ukse taha. Maja välisuks oli ilmselt lahti olnud ja kiisu sisse pääsenud. Väljas olid veel lumehanged. Ka tuul oli sel päeval vali ja ilm ei olnud üldse suurem asi. Minu tütar Hesi ja Juudit hakkasid minema kaubahalli videofilmide laenutusse. Kiisu näugus haledasti, mitte pealetükkivalt, vaid justkui küsides, kas ma sobin teile. Selgus, et sobis küll, ja isegi väga. Õigem on vist ütelda, et kuidas kellelegi.

Juudit küsis Hesi käest, kas ta võib kassile piima anda. Kass nägi üsna armetu välja. Oli kõhn, nälginud ja hirmunud. Lonkas üht jalga ja värises üle kere. See oli umbes nelja kuu vanune tänavakass. Hesi ütles tüdrukule, et viime vanad filmid ära ja võtame uued ning kui tagasi tuleme, anname piima. Juudit kahtlustas, et vahepeal läheb kiisu minema ja palus luba kass filmilaenutusse kaasa võtta. Ta lubas ise kiisut edasi-tagasi tassida. Tehtigi nii.

Kui tagasi jõuti, viidi kass tuppa ja anti talle süüa. Kiisu lakkus piima. Siis tuli, nühkis ennast lipitsevalt lapse vastu ja läks uuesti piima lakkuma. Juudit hakkas paluma, et lubatagu kassil tema juurde jääda. Ta ise hoolitseb kiisu eest. Hesi ei tahtnud hulkuvat kassi elamisse jätta ja arvas, et oleks õigem võtta kassipoeg mõnelt tuttavalt. Juudit ajas kangekaelselt peale, et tema tahab endale just seda kiisut ja hoolitseb ise looma eest. Helistati Andresele, kes arvas, et kui tüdruk ikka seda kassi tahab, siis võtku ja hoolitsegu ise näuguja eest. Tüdruk muidugi lubas seda teha.

Seepeale pandi kass kaussi ning pesti sooja vee ja šampooniga puhtaks, pärast föönitati veel kuivakski. See oli ka ainuke kord, kui kiisu lasi ennast tõrkumata pesta ja kuivatada. Muidu ei kannata ta ei tolmuimeja ega fööni häältki, rääkimata sellest, kui tema peale kas või suuga puhutakse. Aga seekord ta ilmselt aimas, et sellest pesemisest sõltub tema perre jäämine ja lasi enda kallal kannatlikult toimetada. Nii saigi üheksane Juudit endale Saara. Või hoopis vastupidi?

Õnneks ei olnud kassi jalavigastus midagi tõsist, sest see paranes mõne päevaga ja lonkamine kadus. Ju oli keegi teda kõvasti löönud.

Miskipärast tunnistas loomake Juuditi kohe oma perenaiseks, magas tema voodis või kusagil mujal Juuditi toas. Põhiliselt ikkagi voodis. Teistega ta nii väga ei suhelnud. Andres ja Hesi ütlesid, et kui tüdruk kooli läks, käis Saara mureliku moega mööda tuba ringi, aeg-ajalt haledasti näugudes.

Kassile toodi kempsuks neljakandiline plastmasskast. Sinna sisse pandi liiva asemel ajalehepaberi ribad. Kiisu hakkas algusest peale talle eraldatud kastil käima. Kassile meeldis puhtus, ajalehti tuli iga päev vahetada. 
Ükskord, kui kast oli jäänud puhastamata, tegi kass oma junnid ahju ette jäetud prügikühvlile.

Ühel nädalavahetusel jõudsin ka mina tütrele külla. Ajasin Hesiga juttu ja küsisin muuseas, kus see kass siis on. Hesi kutsus kassi kolmel viisil: "Kiisu-kiisu! Kiss-kiss! Saara! Saara!"

Kassi ei kusagil. Hesi küsis kõrvaltoas televiisorit vaatavalt Juuditilt, kus kiisu on. Juudit ei osanud midagi ütelda. Vastas, et alles oli siin. Hakati otsima. Vaadati aknast välja katusele, sest kass armastas aeg-ajalt seal peesitada. Aga kassi ei olnud ka seal. Ka Juudit hakkas oma lapsehäälel kassi kutsuma: "Kiisu-kiisu-kiisu! Kiss-kiss-kiss! Saara! Saara! Saara!"

Tulemus jäi samaks. Vaadati läbi diivani- ja kapialused ning -tagused. Otsiti kõigist kolmest toast ja vaadati isegi külmkapi taha. Hakati kahtlustama, et olen loomakese kogemata uksest välja õue lasknud. Ütlesin, et seda ma kindlasti ei teinud. Lõpuks leidis Juudit Saara oma voodi alt kõige kaugemast nurgast. Kass oli vist kuulnud minu trepist tulekut. Ilmselt talle minu rasked sammud ja jäme bassihääl ei meeldinud ning ta puges peitu.

Juudit võttis vastupunniva kassi sülle ja tõi mulle näha.

Saara oli uhke ja ilus valge kass mustade laikudega või must kass valgete laikudega. Kaelus ja kõht olid kassil valged, saba, kõrvad ja kukal mustad. Sõnaga, mustavalgekirju nagu Põhja-Eesti veised. Silmad olid tal helerohelised, kusjuures ühe silma ümber olid valged ja teise ümber mustad karvad. Kui Saara sulle otsa vaatab, saad sa kohe aru, et ta on ka väga tark kass. Ta silmavaade on kuidagi läbitungiv ja ta jääb sulle liikumatult ainiti otsa vaatama. Ta on selline, kes hoolib ja arvestab sinuga, ehkki kassid seda ju enamasti vajalikuks ei pea. Vähemalt arvab nii minu naine Tiina.

Silitasin Saara pead. Kass tõmbas kõrvad peadligi ja vahtis mulle hirmunud näoga otsa. Hakkasin naerma. Minu naer on vist liiga rõkkav. Igatahes hirmutas see Saarat veelgi enam. Ta hakkas Juuditi süles rabelema ja püüdis vabadusse pääseda. Nüüd tegin vana kõutsi häält. Olin kassihääli ja kräunumist õppinud jäljendama juba lapsepõlves ja harjutanud seda nii kõuts Poe kui hiljem ka Kiisu-Miisu peal. Aeg-ajalt linna või alevi vahel jalutades ja mõnd kassi nähes naelutasin ma neid oma kassihäältega paigale ning nad hakkasid tardunult ringi vahtima, otsides, kust see hääl tuleb. Teist kassi leidmata hakkasid nad varsti uuesti liikuma, kuni mu järgmine näugumine nad paigale naelutas. Vahel kiusasin ma mõnd kassi tükk aega, enne kui ta aru sai, et midagi on viltu ja jalga lasi. Kui mul just kurk haige pole, tuleb kassihääl üsna loomulikuna välja.

Saara peale mõjus minu häälitsemine katastroofiliselt. Ta kräunatas ehmunult ja lõi küüned Juuditi kätte. Juudit lasi looma kiljudes lahti ja see tormas, karvad püsti, tagasi voodi alla. Sealt ta muidugi enam välja ei tul- 
nud. Kui ma voodi alla vaatasin, hakkas ta, karvad turris, minu peale susisema. Jätsin Saara rahule ja mõne aja pärast läksin koju.

Järgmine kord, kui ma Hesile külla tulin, olid Juudit ja Saara Andrese toas. See ei olnud Saara meelest kuigi kindel paik, sest ta tahtis Juuditi tuppa pääseda, kui tüdruk sinna läks. Vaene kassike oli väga hädas. Ta piilus ukse vahelt, aga ei julgenud minust mööda minna. Kui ma tema poole vaatasin, tõmbus ta ukse vahelt kohe toa sisemusse. Pöörasin ennast seljaga ukse poole. Ise vaatasin aknaklaasi peegelduselt, mida Saara teeb. Kass hiilis toast välja. Kui ta keset tuba oli jõudnud, keerasin ümber ja haukusin koera moodi. Saara tardus paigale, ajas oma karvad ja saba püsti ning hakkas susisema. Ma hakkasin naerma ja kiisu põgenes Juuditi tuppa.

Kolmandal korral, kui külla tulin, oli kass suures toas. Mind nähes ajas ta kohe oma karvad turri, susises ähvardavalt ja taganes oma varjupaika.

Suvel käis Saara koos pererahvaga suvitamas ja hakkas üsna varsti tublisti kosuma. Ei läinudki kaua, kui oli selge, et selle põhjuseks pole toores kala ega värske maaõhk. Saara ootas poegi.

Millal need täpselt tulevad, ei osanud keegi öelda. Saara kõht aga aina paisus. Ühel õhtul, kui Juuditi sõbranna ööseks tema poole jäi, käitus kass kuidagi rahutult. Viimaks mahutaski loom end tüdrukute vahele tugitooli magama, mida ta varem polnud teinud. Korraga, keset ööd, mäugus loom kõvasti ja kloppis käppadega tekki, tahtes justkui öelda, et ärka nüüd üles, pole siin aega magada enam midagi.

"Eks ma aimanud, et varsti hakkab ta poegima, aga täpselt ei kujutanud ma küll asja ette. Jäin magama ja ärkasin, sest äkki oli kass minu teki all. Ning midagi külma ja limast surus end mu vastu," meenutab Juudit ehmatust, kui märkas teki alla lamamas väikest limast kassipoega. Järgmine päev oli koolipäev, ent tüdruk arvas, et peab kassi poegimise pärast koju jääma. Et aitab looma ja on talle toeks.

Pojad olid ilusad ja terved ning kasvasid jõudsasti. Esialgu olid nad väiksed ja Juudit tõi nad meile vaadata.

Minu külaskäik tekitas Saaras alati paanikat. Alati susises ta minu peale ja varjus oma peidukohta. Poegadega kassi ma oma kräunumisega hirmutama ei hakanud, aga see enam ei lugenud. Saara oma käitumist minu suhtes ei muutnud. Iga kord, kui ma tütrele külla tulin, kordus kõik. Kass susises ja varjus, karvad turris, Juuditi tuppa. See näitas, et minu kui ohtliku isendi kohta oli kiisul kindel arvamus.

Pojad kasvasid ja hakkasid mööda korterit ringi jooksma. Kui ma seal olin, jooksid nad ka minu juurde. See traumeeris Saarat väga, ta hakkas poegi ükshaaval turjast kinni võttes külalistetoast Juuditi tuppa vedama. Aga ega pojad voodi all püsinud. Kui ta ühe oli voodi alla viinud, oli teine 
samal ajal juba tagasi külalistetoas. Vaatamata sellele, et Juudit kassi sülle võttis ja Saarat rahustas, katsus loom tema sülest pääseda ja kui pääses, hakkas jälle poegi külaliste juurest eemale tassima. See kordus seni, kuni külalised lahkusid.

Pojad kasvasid ja jõudis kätte nendest lahkumise aeg. Õnneks leidis Hesi sõbranna ja klassiõde Marge kolm tuttavat, kes olid nõus ilusad kassipojad endale võtma. Neljas poeg õnnestus ära anda kuulutuse peale helistanud tudengile.

Natukene aega oli Vallikraavi tänavas taas vaikne. Kui poegi enam ei olnud, oli Saara algul väga närviline. Ta otsis neid siit ja sealt ning näugus haledasti. Mõne aja pärast muutus Saara rahulikumaks, kuigi minu haukumine talle ikka eriti ei meeldinud.

Saabus Juuditi 9. sünnipäev. Sünnipäev oli nagu lapse sünnipäev ikka. Sugulased tulid kokku ja aeti juttu.

Mõni aeg hiljem kinkis Juuditi ema isa juures elavale tütrele kääbusküüliku. Kujutage ette isast küülikut, kes mööda tuba ringi kalpsab ja siiasinna oma pabulaid puistab. Kui Saara oli väga puhas loom, kes ilusasti kassikempsus käis, siis küülik oli näide anarhiast. Ta istus oma puuris ja ragistas hammastega puurivõresid. Seda tegi ta närviliselt ja enneolematult tugevasti. Puur naksus ja värises, kui küülik võresid näris. Sellega näitas ta, et soovib puurist välja saada. Juudit oli hea tüdruk, kes soovis loomakesele ainult head. Pealegi oli see armsa ema kingitus. Seega ei saanud Juudit küüliku puuris piinlemist rahulikult pealt vaadata ja tõstis loomakese sealt välja. Küülik rõõmustas seepeale muidugi silmanähtavalt. Niipea, kui ta puurist põrandale tõsteti ja jalakesed põrandat puudutasid, hakkas ta põrandale pabulaid puistama. Lasi paar pabulat, kalpsas mõned hüpped edasi ja lasi jälle paar pabulat. Ma tegin Juuditile nalja ja ütlesin, et pead küülikule koti saba külge siduma, siis saad ilma pühkimata pabulad kätte. Nüüd aga oli kogu aeg vaja põrandat koristada, kui ei tahtnud pabulaid jala all laiaks vajutada.

Küülikul oli veel üks omadus, mis näitas mõningal määral isegi looma nutikust. Kui ta süüa tahtis, võttis ta kausi hammaste vahele ja hakkas seda vastu maad taguma. Seda tegi ta nii puuris istudes kui ka vabana toas olles. Siis anti talle sinna kaussi muidugi krõbisevat küülikutoitu. Kui küülik oli kuhugi varjunud ja teda taheti kätte saada, tuli ainult raputada krõbinatega toidukarpi ja küülik ilmuski peidust välja.

Hesi sai kuuks ajaks stipendiumi enesetäienduseks Göttingeni Ülikoolis. Selleks 2001. aasta juunikuuks sõitsid Göttingeni ka Andres ja Juudit. Vae- 
ne Saara jäi üksi Vallikraavi tänava korterisse. Keegi pidi kurva kassikese eest hoolitsema.

Arstid olid diagnoosinud mul allergia kasside vastu. Kui see uudis mulle teatavaks tehti, imestasin väga. Olin ju terve lapsepõlve kassidega koos elanud ja mingit probleemi ei olnud. Kuid see oli hea ettekääne, et tüütu kassi toitmise kohustus Tiina kaela sokutada. Asi kujunes küll nii, et mina pidin ta autoga Vallikraavi tänavasse viima ja ega ma siis autosse ootama jäänud, kuni ta Saaraga toimetab. Huvitav oli see, et nüüd, kui pererahvast kodus ei olnud, suhtus kass minusse hoopis teistmoodi. Ta tervitas meid alati õrnalt näugudes, ihkas silitamist ja tuli nurrudes ennast vastu Tiina ja minu jalgu nühkima.

Et Tiina pidi tihti Tallinnas käima, jäi kiisu ajuti täiesti minu hoolde. Sellistel puhkudel käitus Saara minuga kui parima sõbraga. Nurrus, ronis sülle ja jäi väga kurvalt mulle järele vaatama, kui ma ta diivani peale panin ja lahkumiseks ukse poole hakkasin minema. Vahel ta lasi kuuldavale õrna näu, kurvastamaks, et sa ära lähed.

Küülikut hoidsime pereliikmete äraolekul puuris ja arvatavasti mõjus selline kuuajaline vangistus talle traumeerivalt. Oli ta ju harjunud vabaduses mööda korterit silkama. Meil ei olnud aga aega temaga mängida. Puhastasime puuri ja andsime süüa. See looma muidugi ei rahuldanud. Ta võttis hammastega puuri traatidest kinni ja püüdis neid ragistades märku anda, et tahab jalutama minna.

Kui Hesi pere koju tagasi jõudis, toimus täielik muutus. Kui külla tulin, ei teinud kass minust enam väljagi. Isegi kutsumisel ei tulnud ta enam minu juurde, vaid viibis ikka Juuditi või kellegi teise juures. Suve viimase kuu veetsid nad taas Alajõe maamajas.

Kui Saara ka pärast seda suve kosuma hakkas, ei arvanud enam keegi, et see tuleb värskest õhust ja heast elust. Kui kass oli juba parajalt ümar, oli selge, et varsti peab valmistuma pere suurenemiseks. Et asi aga just nüüd kahtlaseks kisub, oletas Juudit sellest, et Saara oli õhtu otsa väga elav, otsis lähedust ega lasknud tüdrukut sammugi eemale. Ka pimedas püsis Saara Juuditi juures ja jäi ta teki alla magama.

Kella nelja paiku öösel ärkas tüdruk selle peale, et kass väristas end teki all ja näugus, justkui paludes, et ta temaga koos üleval oleks. Mõni aeg ei juhtunud midagi, siis aga tegi kass väga suure mäu.

"Nägin poolenisti väljaulatuvat kassipoega ja siis mäugus Saara jälle. Mina ehmatasin, kutsusin isa appi. Isa oli väga rahulik. Ta otsis panipaigast vana vesti, tõi ühe tühja kasti ja tegi kassile mõnusa aseme. Isa lootis, et juba eelmisest poegimisest tuttav vest rahustab looma," meenutab tüdruk. 
Aga siiski sünnitas kassike oma seekordse esimese poja jälle tüdruku voodisse.

"Ja kas sa üldse tead, et ega's kassil kõik pojad korraga sünni," vaatas Juudit mulle umbusklikult otsa. Ei teadnud jah. Ja tüdruk seletas, kuidas asi oli. Möödus tund ja 45 minutit, kui pärast esimest poega sündis järgmine, siis oli jälle tund vahet. Und Juuditil muidugi ei tulnud, pealegi tuli tal vaadata kassipoegade järele, et neil halb poleks. Ja kuidas sa saadki magada, kui nii põnev on teada, kas sünnivad valged, mustad või hoopis pruunikirjud kassilapsed. Magama jäi ta alles hommikul kuue paiku.

Kuid Saara ei tahtnud hommikulgi Juuditist lahkuda. Kui tüdruk teise tuppa läks, hakkas Saara kurvalt näuguma. Nagu ütleks: sa ei tohi ära minna. Juudit tahtis poegi teise tuppa viia ja teistele näidata, kuid kassiema ei lubanud - näugus väga närviliselt ja haaras Juuditil käest. Kui tüdruk järgmisel päeval siiski kooli läks, oli Saara üpris kurb.

Pojad kasvasid. Ka küülik kasvas. Mida vanemaks küülik sai, seda isasemaks ta muutus. Lõpuks oli ta nii kiimas, et püüdis kassi karata. Nii kui kass kuhugi põrandale istuma jäi, hakkas isaküülik teda kohe ründama. Kass andis talle sellise üleannetu käitumise eest käpaga üle nina või vastu kõrvu ja kõndis eemale. Küülik raputas peale laksu saamist pead, aga ei taltunud, vaid hüples kiisule järele. Saaral oli arvatavasti igav, sest ta hoidis parajat vahet ja jalutas mööda tuba. Kui küülik liiga ligidale jõudis, kiirendas kass sammu. Nii mängis Saara küülikuga tükk aega. Kui ta lõpuks sellest mängust tüdines, hüppas ta mõne kõrgema koha peale, kuhu küülik ei pääsenud.

Aeg-ajalt viidi isane kääbusküülik külla mõnele emasele küülikule, kelle peremees väikseid küülikuid soovis. Aga sellele vaatamata vaevas küülikupapat pidevalt sugutung. Enamiku ajast pidi vaene kass istuma toolil või laua peal, aknalaual, diivanil jne. Küülik vahtis siis kiimas näoga all. Nii kui kass põrandale tuli, asus küülik teda kiusama. Ma olin näinud ja kogenud varem küll seda, et mõni kiimas koer inimese jalga ründab ja püüab selle vastu oma himusid rahuldada, aga sellist kiimlevat küülikut nägin esimest korda elus. Küsisin nalja pärast Hesi käest, kas nüüd on pikkade kõrvadega karvaseid kassipoegi oodata.

Kui Saaral ei olnud veel poegi, suhtus ta küüliku tegevusse taunivalt, aga ei hakanud karvakera füüsiliselt karistama. Tüdinedes ronis lihtsalt kõrgemale ja kõik. Poegadega kass käitus hoopis teisiti. Kui küülik nüüd mööda tuba ringi kalpsas ja kassipoegadele lähenes, lõi Saaras välja emainstinkt ja ta asus poegi kaitsma. Küüliku kassipoegade lähedusse jõudmisel tegi Saara oma esimese hoiatuse: ajas karvad kohevile ja saba püsti ning 
hakkas susisema. Loll küülik kalpsas aga edasi ja püüdis kiimalisena hoopis Saarat rünnata.

Saara on muidu väga kannatlik kass ja laseb ennast nii- ja teistpidi väntsutada. Seekord sai tal lollist karvakerast aga isu täis. Kass võttis küülikul turjast ja raputas teda üpris korralikult. Kui Hesi ja Andres koju tulid, leidsid nad eest väga apaatse küüliku. Kiisu oli teda õige tugevasti kaelast muljunud. Küülik viidi loomaarsti juurde, kes vaatas looma läbi ja tegi süsti. Natuke aega pidi loom puuris veetma.

Varsti oli ta jälle liikvel. Oma viimasest kohtumisest Saaraga ei olnud ta aga õppust võtnud. Karvakera kalpsas jälle voodi alla, kus olid kiisupojad. Kass võttis küülikul turjast kinni, tiris ta voodi alt välja, raputas tugevasti ja lasi siis lahti. Kindlat jalgealust uuest tundes raputas küülik pead ja hakkas uuesti kassipoegade juurde trügima. Saara võttis tal jälle turjast kinni ja hakkas raputama. Kõlas tugev prõks ja enne kui Andres küülikule appi jõudis, oli vaesekese hing maisest kehast lahkunud.

Juudit oli väga kurb ja nuttis isa juures kassi teo pärast. Isa lohutas last ja tõi talle uue küüliku. See oli väljanägemiselt peaaegu samasugune kui eelmine. Sarnasuseks oli ka põhjust, sest see oli eelmise küüliku poeg. Emase küüliku omanik, saades kuulda isaküüliku kurvast saatusest, kinkis viimase järelejäänud poja Juuditile vastutasuks paaritusteenuse eest. Uut looma hoiti esialgu puuris, et karvakera ei tabaks eelmise küüliku kurb saatus.

Kassipojad aga kasvasid ja jälle oli kätte jõudnud poegade äraandmise aeg. Otsiti kassisõpru lähedalt ja kaugelt. Hesi ja Andres pani kuulutused mitmesse lehte. Kuulutati ka Tartu Ülikooli listis ning Tartu raadio pakkus ilusaid ja väga targa kassiema poegi. Ka Tiina lülitus kassipoegadest lahtisaamise programmi. Esimese kassipoja võttis endale Maaris. Juudit ise viis loomakese kohale ja andis lastele üle. See oli pesakonna kõige elavam ja üleannetum, kes ronis pidevalt igale poole. Välimuselt oli ta ilus valge pruunide täppidega kiisu. Kassipojaga olid kõik rahul. Lapsed poputasid, aga mingil hetkel oli loom kappi pugenud ja ukse sulgemisel peadpidi kapiukse vahele jäänud. Ning armast kassikest ei olnud enam. Lapsed nutsid.

Juudit oli käinud aeg-ajalt vaatamas, kuidas Saara kena lapsuke elab. Keegi ei julgenud tüdrukut selle koleda uudisega traumeerida. Alles siis, kui Juudit mõne aja pärast kassipoega vaatama tahtis minna, sai ta teada kogu tõe. Kolm kassipoega oli veel järel ja Juudit tegi ettepaneku, et nende hulgast antakse Maarisele asenduskass. Nii ka tehti.

Kahest järgmisest pojast lahtisaamine võttis aega mis võttis, aga lõpuks leiti neilegi kodud. Kuigi seekord hakkas mulle juba tunduma, et kassipoegi ei taha enam keegi ja lahti neist ei saagi. 
Elu kulges vana rada. Suveks mindi maale, kus ka kass Saara päikest ja piisavalt värsket õhku pidi saama. Oli ta ju oma puude- ja seega ka päikesevarjus olevas korteris linnaelust tüdinenud. Alajõel ootasid kassi ka tema suvekallimad. Need olid igaüks eri värvi: must, valge ja hall. Kõige meeletum ja iharam oli must. Ta ronis Saara juurde maja teise korruse akna kaudu, pööramata tähelepanu sellele, et inimesed olid toas. Andres ajas kõutsi õue, aga enne, kui ta trepist teisele korrusele jõudis, oli must kass seal juba tagasi. Ei aidanud muu, kui tuli aken sulgeda.

Oma kolmandat poegimist aimas kassiema ette. Saara oli aastatega targemaks saanud. Ta muutus rahutuks, nühkis end vastu Juuditi jalgu ja käis toast tuppa. Kui Juudit õhtul sõbrannaga ujuma läks, oli Saara üsna õnnetu moega. Juudit taipas, et ega seegi kord kass temata hakkama saa ja leppis isaga juba ette kokku, et järgmisel päeval ei tule kooliminekust miskit välja. Aeg venis, Juudit istus parajasti teleka ees, kui Saara kell 11 poegima hakkas. Poegi oli jälle neli.

Pärast lakkus Saara pisipere puhtaks. Aga et tal juba varasemast oli kombeks voodisse poegida, tuli nüüdki linad ära pesta. "Kassil on küll paks veri, aga pesupulber on ikka tugevam,” arvas Juudit. Ja tõesti - pesupulber kõrvaldas linalt vereplekid alati lausa nagu reklaamis.

Kassipojad kasvasid ja jõudsid äraandmisikka. Seekordne kassipoegadest lahtisaamine läks kõige vaevarikkamalt. Hesi ja Andres panid jälle kuulutused lehtedesse. Neid avaldasid Soov ja Postimees. Loomulikult oli kuulutus Tartu Ülikooli listis ja internetis, Tartu Raadio pakkus jälle väga ilusaid ja väga targa kassiema poegi. Ja ega mind ja Tiinatki kassipoegadest lahtisaamise programmist kõrvale jäetud. Andres sõitis ühe kassipoja äraandmiseks spetsiaalselt Võrru ja teise pärast Tallinna. Lõpuks leidsid kõik loomad endale peremehe.

Küsisin Juuditilt kui kassiämmaemandalt, milliseid kogemusi ja teadmisi ta sooviks teistega jagada. Juudit ütles järgmist:

- kui kass poegib ja sa oled ta lemmikpereliige, ei tohi sa lihtsalt ära minna ja teda hätta jätta - ka kass soovib, et sel tähtsal hetkel tema juures ollakse;

- tegelikult oli ehmatav ainult esimene kord, sest siis ei teadnud ma veel midagi ega osanud ka midagi ette võtta;

- kõige jubedam oli teine kord, kui ma nägin kassipoega, kes oli poolenisti sündimata. Läksin veidi paanikasse ja kutsusin isa. Tema oli rahulikum, otsis kasti ja lambanaha ja siis tegime Saarale pesa;

- minu meelest oli huvitav ka see, et vähemalt teise ja kolmanda pesakonna pojad olid kahe isakassi pojad. Kassid nimelt suudavad mitme isa poegi korraga ilmale tuua. Üks esimese pesakonna isadest oli kindlasti naabri- 


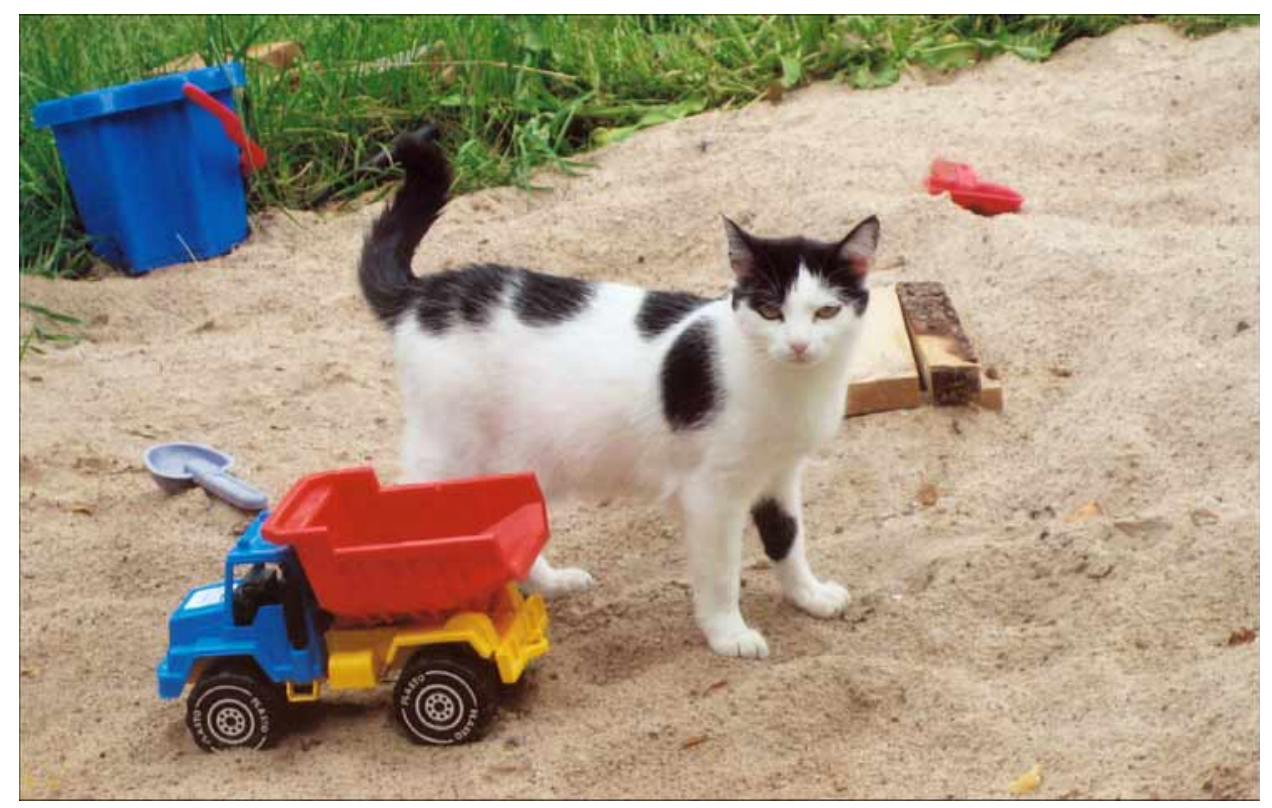

Foto 1. Saara ja Joosepi auto.

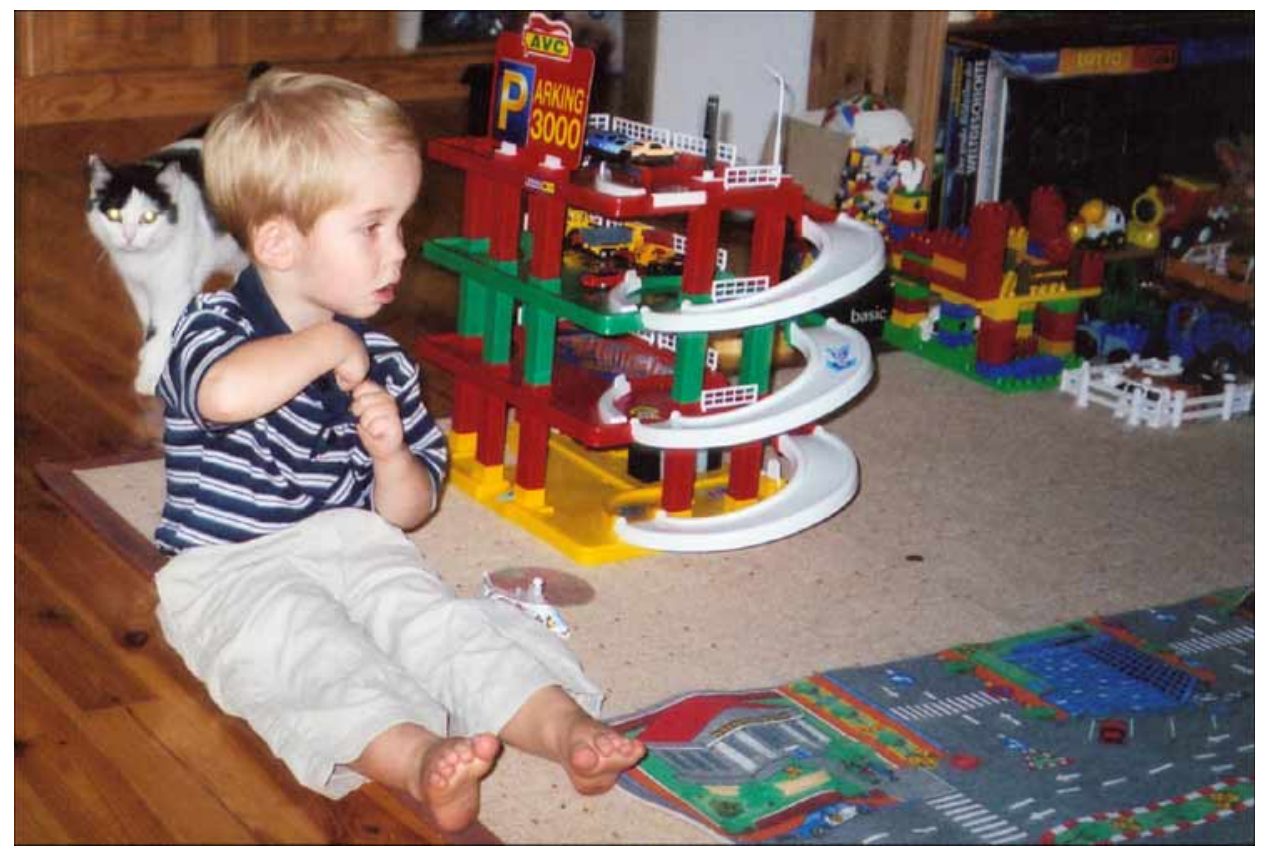

Foto 2. Mänguhoos. Ülo Siimetsa fotod 2006. 
kass Alajõel, kus Saaral on veel mitu peiut. Saara on väga kena kassineiu. Nägin, kuidas must ja valge võitlesid omavahel, kes Saara endale saab. Mis teha, sealkandis pole ju palju ilusaid emaseid.

Küsimusele, kas ta plaanib loomaarstiks õppida, vastas Juudit elutargalt, et seda on vara öelda ja pikemalt pole ta seda mõelnud. Aga vähemasti oskab ta juba kassi poegimisel aidata.

Ehitasime Ihaste suvila ümber elamuks. 4. oktoobril 2003 sündis Joosep. Hesi, Andres, Juudit ja väike Joosep kolisid 2004. aasta veebruaris Ihastesse uude majja. Kaasa võeti ka Juuditi lemmikloomad.

Uues majas näitas Saara esimest korda, et ta tahab olla tähelepanu keskpunktis. Hesile ja Andresele tuli külla Jane. Ka Tiina oli seal. Saaraga ei tegelnud keegi ja muidugi ta solvus. Kass hüppas demonstratiivselt köögikapi nõuderiiulisse, vaatas toasolijatele otsa ja sirtsutas uue kapi riiuli ja nõud täis. Kassikemps oli puhas. Sinna oli pandud puhas ajaleht, mille peale oli valatud puhas Kittyfriendi puru. Ainuke selgitus sellise käitumise kohta on kättemaks.

Saaral olid jälle pojad. Seekord kaks poega. Vahel kohtusime trepikojas. Saara ei tahtnud mind jälle tunda, vaid ajas karvad turri ja saba püsti ning susises minu peale. Ju oli tal jälle hirm oma poegade pärast. Juudit käis küülikuga õues jalutamas. Ka kass lasti aeg-ajalt jalutama. Toas hoiti küülikut puuris.

2004. aastal sai Hesi taas stipendiumi Göttigeni Ülikooli juurde ja sõitis Saksamaale. Varsti sõitsid ka Andres, Juudit ja Joosep talle järele. Nad olid ära juunist juulini. Kassipojad kasvasid ja jõudis kätte järjekordne pereheitmisaeg. Juuditil õnnestus sokutada üks poegadest vanaemale, teine jäi esialgu Saara juurde.

Septembris sõitsid Hesi ja Andres koos lastega tööle Luksemburgi.

Majja võeti tudengitest üürilised. Nendega oli sõlmitud üürileping, kuhu oli lisatud punkt, et üürilised hoolitsevad ka koduloomade eest. Saarale uued inimesed ei meeldinud. Ta oli harjunud elama elutoas, kuid nüüd tõsteti ta koos küülikuga koridori. Vahel õnnestus tal ka tuppa pääseda ja uudishimulik, nagu ta oli, hüppas ta laua peale. Üürilisele (Argole) kassi familiaarsus ei meeldinud. Ta andis loomale laksu ja viskas põrandale. Juuditi poputamise ja õrna kohtemisega harjunud kiisule oli see enneolematu ülekohus. Pealegi kadus ootamatult ära tema viimane poeg (üürilistel õnnestus see anda Pärnus elavale tuttavatele). Võib-olla nägi kass, kui ta poeg kotti pandi ja autosse viidi. Igatahes kuulutas ta üürilistele sõja, milles sai kannatada terve elamine. 
Kassi kättemaks oli väga haisev. Kui loom tuppa pääses, sirtsutas ta üüriliste voodisse või riietele. Ta jättis oma väljaheiteid kõikvõimalikesse kohtadesse: trepile, vaibale, saunaahju taha, kaminasse jne. Ta otsis kogu aeg uusi kohti. Mõned neist olid välja mõeldud ehtkassiliku kavalusega. Näiteks sittus ta mitmed korrad pärast üüriliste loengusse minekut suletud uste taha. Kui tudengid nüüd koolist tulid ja ukse avasid, lükkasid nad kassirooja kõigepealt ukse alumise servaga laiali ja astusid selle sisse. Eriti hull oli olukord siis, kui nad enne seda olid koridoris kingad jalast võtnud.

Tudengitel käisid külalised ja siis istuti kaminaruumis nahkdiivanil, joodi õlut ja tehti kaminasse tuld. Kass kraapis kättemaksuks küüntega puruks nahkdiivani käsitoe külje ja seljatoe naha. Ta ei saanud aru, et maja on välja renditud ja need asjad ei kuulu üürilistele. Kui ta kaminaruumi pääses, reostas kohe kamina ära. Ka kaminaruumi diivani taha tegi ta pidevalt hunnikuid.

Väga võigas oli saunaahju taha sittumise komme. Kui sauna köeti ja leili visati, hakkas saun hirmsasti haisema. Tudengid koristasid sauna ära. Aegajalt kuivatasid nad sauna suures eesruumis pesu ja kui nad olid ukse lahti jätnud, kasutas kass olukorra ära: peitis ennast saunalava alla ja kui vaikseks jäi, roojas ahjutagusesse. Vahel ütlesid noored, et nad olid ukse kinni pannud, aga hiljem selgus, et uks oli ikka lahti ja ruum reostatud. Ka pestud riietele kippus hais juurde jääma. Siis jäeti tuulutamiseks saunaaken lahti. Kass ronis saunaaknast sisse, reostas saunaahjutaguse ära ja ronis akna kaudu uuesti välja. Nii kordus see mitmeid kordi. Üürilised olid sunnitud kas akent kinni hoidma või akent ainult nii palju lahti hoidma, et kass sisse ei mahuks.

Kõige hullem roojamiskoht, mida ei olnud ka võimalik koristada, oli trepialune. Seal oli nii väike ava, et sinna tulnuks kõhuli roomata. Seega oli sealt peaaegu võimatu koristada. Tudengid kas ei avastanud seda, kui nad seal elasid, või ei hakanud selle koristamisega mässama.

Ega need tudengid näidanud vist loomade vastu üles ka erilist armastust. Mingi aja pärast suri küülik. Ta lihtsalt leiti ühel hommikul puurist surnuna.

Ka kass viibis nüüd väga palju õues ja jäi vahel mitmeks päevaks kadunuks. Aeg-ajalt tekkis tunne, et enam ta tagasi ei tule. Aga tuli siiski. Tühi kõht oli hea tagantsundija. Eks ta püüdnud õues ka linde, sest siin-seal leidus mõnikord linnusulgi ja verd.

Üürilised andsid kassile tiinestumisvastaseid tablette, aga vaatamata nendele sündis Saaral üks poeg. Muidugi oli kiisu jälle närviline.

Poja suuremaks saades jooksid nad koos koridoris ringi. Kui mina tulin, varjusid mõlemad. Nad peitsid ennast koridoris olevate asjade (kastide) 
taha. Kassipoeg pistis uudishimulikult pea kasti tagant välja, aga Saara urises ja poeg tõmbus kohkunut tagasi.

Aasta sai läbi ja ühes sellega ka üürileping. Õigemini algas koolivaheaeg ja tudengid sõitsid suveks koju. Kass pidi nüüd põhiliselt minuga leppima. Kui poeg veel ringi jooksis, oli ta ettevaatlik ega tormanud kohe minu juurde, vaid jälgis minu tegevust kaugemalt. Tiinal õnnestus anda kassipoeg lõpuks töökaaslasele Kristale. Enne pidi ta muidugi loomakest põhjalikult kiitma. Hakatuseks rääkis ta, kui tark ema pojal on, siis sellest, kui ilus ja puhtustarmastav kiisupoeg on ning kuidas pojuke oskab juba ise süüa. Tegelikult me ei teadnud, kas ta oskab süüa või kas ta käib kastil. Seda võis ainult oletada sellest, et maja ei olnud ära reostatud. Pärast poja üleandmist selgus, et ta on tõesti väga tubli: sööb ja käib korralikult kastil. Krista ja eelkõige loomulikult tema lapsed olid kiisukesega väga rahul.

Paar nädalat peale poja äraandmist toimus Saaras muutus ja see oli põhjalik. Nüüd olin mina talle toidu- ja hellustejagaja. Saarat ei olnud võimalik enam ära tunda. Enam ei poetanud ta kuhugi ühtegi hunnikut. Minu saabumisel tervitas ta mind haleda näugumisega, nagu soovides öelda, et ei ole sind kaua näinud, kus sa olid? Seejärel hakkas ta ennast vastu minu püksisääri hõõruma ning jooksis külmkapi juurde ja jäi ootele. Kui talle kohe süüa ei antud, hakkas ta käpaga külmkapi ust kraapima. Kui ma ka siis meelega talle veel süüa ei andnud, vaid võtsin näiteks hoopis põrandaharja ja hakkasin tuba pühkima, jooksis ta minu juurde ja hakkas küüntega minu püksisäärt kraapima. Siis tuli talle muidugi süüa anda.

Samas ei jäänud kiisu minust enam sammugi maha. Isegi kui tal kõht tühi oli ja ma tahtsin ära minna, jooksis ta mulle järele. Kui ma ta üksi toidukausi juurde jätsin, ta lihtsalt ei söönud. Järgmisel päeval tagasi tulles oli toidukausis nii palju toitu, nagu oli minu lahkudes sinna jäänud. Vana toitu ta ei tahtnud. Selleks, et ta eelmise päeva toidu ära sööks, tuli kiisule võtta uus taldrik. Taldrikule tuli panna kihiti vana, eelmise päeva toit ja värske Whiskas või Kitekat. Erilist söögiisu tal siis ei olnud. Pidin tema kõrval seisma või istuma, kuni ta sõi. Aeg-ajalt tundis ta vist vana toidu maitset, igatahes tõstis ta pea ja vaatas mulle küsivalt otsa. Ütlesin siis talle, et söö, söö ja ta tegi taldriku puhtaks.

Saarale tableti andmiseks tuli taldrikule panna hästi vähe kassitoitu ja tablett sinna keskele ära peita. Kui tablett oli liiga alla pandud, söödi söök pealt ära ja jäeti tablett ikka alles. Siis tuli peitust korrata, aga mingi tableti lõhn oli üleval ja ta ei tahtnud süüa. Taldrikule koputamine ja ütlemine “söö, söö!" mõjus, siis söödi taldrik puhtaks ja vaadati teraval pilgul otsa, et 
kas ma olen rahul. Tegin siis talle pai ja andsin natuke suurema koguse kassitoitu.

Vahel panin talle söögi kaussi ja hakkasin televiisorit vaatama. Saara sõi natukene ja tuli minu juurde ning vaatas mulle väga teraselt ja ootavalt otsa. Kui patsutasin käega põlve peale, hüppas ta mulle põlvedele. Kui ma aga ei patsutanud, vaid ütlesin: “Mine, mine, söö oma söök ära!” läks ta toidukausi juurde ja hakkas sööma. Natukese aja pärast tuli ta jälle minu juurde ja vaatas otsa, et kas nüüd võib sülle tulla. Eks ma siis lubanud ka.

Saaral oli veel üks huvitav omadus - ta ei joonud vett põrandale asetatud kausist, aga kui vesi oli kraanikaussi asetatud kausis või kruusis, kõlbas see juua küll. Hesi ja Andres tegid sellise käitumise kohta nalja, öeldes, et kass kardab, et ta ära mürgitatakse.

Kui ma õue läksin, tuli Saara ka välja. Istus minu kõrval murul või kännu otsas. Kui tõusin püsti ja kõndisin aias ringi, jalutas kass minu sabas nagu kutsikas. Vahel tegin meelega tiiru ümber maja, vaadates, kuidas kiisu käitub. Ta kõndis minu sabas seni, kuni jõudsime meie ja naabri piiril oleva võrkaiani. Siis jäi Saara maja nurga juurde seisma ja piilus nurga tagant, mis toimub. Naabri koerad olid harjunud minu käest konte saama ja tormasid minu juurde. Saara varjus nurga taha ja jäi sinna passima. Kuigi maja ja aia vahe on üle meetri, tundus kiisule vist ikka, et kutsud pääsevad talle liiga lähedale ja ei julgenud edasi tulla. Kui läksin tuppa, tuli ka Saara. Kui istusin tugitooli televiisorit vaatama, istus kass algul põrandal. Mõne aja pärast tegi Saara asja minu kõhu või rinna peale ja hakkas oma käppadega mind mudima, ise nurrudes. Vastutasuks siis pidin mina teda silitama ja mudima tema kõhtu, mille ta mulle ette keeras.

Korra olime rõdul ja Saara kõndis mööda rõdu äärt. Naabri kass - mustvalge kõuts - tuli meie aeda ja jäi meie rõdu alla Saarat uudistama. Keerasin kiisu näoga võõra kassi suunas ja ütlesin: "Võta!" Saara hüppas rõdu ääre pealt alla võõra kassi suunas ja hakkas teda taga ajama. Võõras kiisu jooksis ees, Saara taga. Nii jõuti naabermajani, kus kõuts lauahunniku vahele varjus. Selliseid olukordi oli mitmeid.

Ühel päeval olime jälle õues. Istusin aiatoolis ja lugesin. Saara lebas mu süles ja ma silitasin teda aeg-ajalt. Korraga Saara erutus ja kargas minu põlvedele püsti. Tõstsin pea ja nägin hästi suurt üleni musta kassi, tõelist hiiglast, meie heki alt välja tulemas. Välimuselt oli ta nagu must panter. Temas oli tunda jõudu ja võimu. Ütlesin Saarale: "Võta!" Saara tormas võõra kassi suunas, aga see ei kõssanudki. Hoopis istus maha ja ootas, kuni meie kiisu temani jõudis ja tegi siis himura näu. Saara lõpetas kohe jooksmise ja astus väärikal sammul musta hiiglase suunas. Nad nuusutasid tei- 
neteist ja ma arvasin kuulvat ka nurrumist. Kui ma toolilt püsti tõusin, taandus võõras kass heki taha. Saara tuli minu juurde. Mõnikord nägin seda kõutsi kusagil meie majast kaugemal jalutamas. Meie õue peal kohtasin teda uuesti kasside indlemise ajal.

Vahel näugus Saara välisukse juures ja küsis õue. Kui ilm oli külm, astus ta trepile, nuusutas õhku ja tuli kohe tuppa tagasi. Sooja ilmaga lasin ma ta õue ja kiisu käis oma kassiringe. Kui Saara minu töölemineku ajaks tagasi ei tulnud, jäigi ta terveks päevaks õue. Õhtul, pärast tööd ilmus ta automürina peale näugudes kusagilt välisukse juurde. Kui hiljemaks jäin, oli ta kadunud. Teda otsides leidsin ma vahel ta aiast maalripukkide otsast või puuriida pealt. Minu kutsumise peale hüppas ta sealt alla ja tuli joostes ning pahaselt näugudes nagu kaeveldes minu juurde. Mõnikord ilmus ta välja alles siis, kui hõikasin: "Kiisu-kiisu! Kiss-kiss! Saara! Saara!”

Hesi, Andres ja lapsed saabusid puhkusele. Juudit hakkas tegelema kassiga. Kui kiisu tema sülest pääses, ajas Joosep Saarat taga. Saara ei olnud harjunud Joosepi hõikamisega ja jooksis paaniliselt tulistjalu poisi eest ära. Minusse suhtus Saara sel ajal ükskõiksemalt kui muidu.

Puhkus lõppes ja tütre pere sõitis tagasi Luksemburgi. Kass oli jälle minu parim sõber. Seda sõprust jätkus kogu külma sügise, talve ja kevade.

Kahel korral olid meil külalised, kes jäid ka ööbima. Mõlemad olid meesterahvad. Tundus, et Saara saab nendega hästi läbi. Ta oli isegi nõus ennast silitada laskma. Järgmisel päeval pärast külaliste lahkumist tegi ta trepi peale hunniku. Seda mõlema külalise korral, justkui andes mõista, et ärge tooge siia igasuguseid elama, mulle see ei meeldinud. Muidu on Saara väga puhtustpidav kiisu, aga iseloom paistab omapärane olevat.

Hesi ja Andres saabusid lastega koju. Joosep oli nüüd suurem ja jõudis kassi isegi sülle võtta. Tema kassikandmine näeb küll välja nii, et ta võtab kassil selja tagant kõhu ümbert kinni ning tõstab looma üles. Kuna tagajalgadel seisev kass on peaaegu sama pikk kui poiss, jäävad kassi jalad mööda maad lohisema. Saara teeb siis õnnetu näo pähe. Vahel ta isegi näub kurvalt.

Ka kassi kallistamine on rohkem kassi lämmatamise moodi. Joosep viskub vahel põrandal olevale kassile terve kehaga peale ja teeb talle siis kallikalli. Kass on nii laiaks vajutatud, et tal ei jätku hingamiseks õhku ja tal on tegemist, et poisi alt ja käest pääseda. Kui kiisu on diivanil, läheb tal kergemini, sest siis ulatub Joosepil ainult pea ja ülakeha kassi kallistama. Kassi paitamine on ka tore asi. Poiss võtab kassi kasukast kinni ja raputab kiisut siia-sinna. 


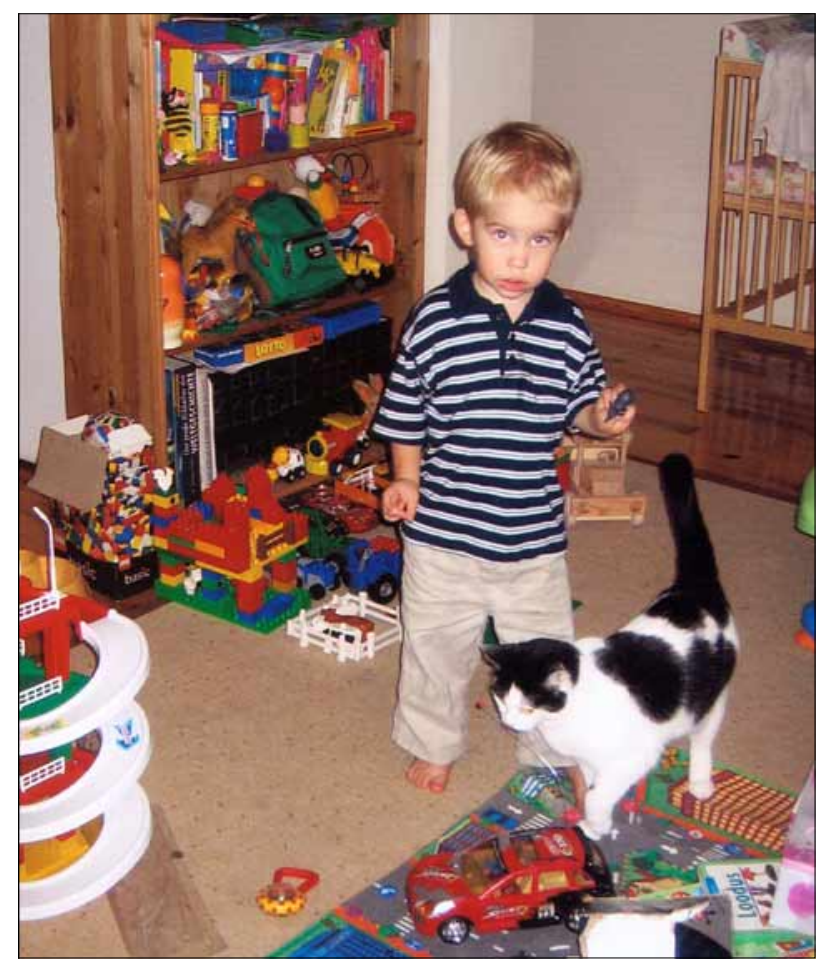

Foto 3. Sõbrad. Ülo Siimetsa foto 2006.

Kõige selle juures on huvitav, et Saara kräunub nii haledalt, et Hesi ja Andres ruttavad talle appi, aga kass ise ei hammusta ega küünista poissi kunagi. Ta ei jookse ka eest ära, vaid astub rahulikult ja väärikalt kakskolm sammu poisist eespool. Vahepeal laseb ta poisil tõkkeid ületada. See tähendab, et kiisu poeb tooli alt läbi või läheb seina ääres oleva diivani ja tugitooli tagant läbi. Joosep on veel nii väike, et ei näe üle diivani käe- või seljatoe, et kiisu on diivani tagant juba kadunud, kui tema ise veel seal turnib. Kass ootab teda, saba aeglaselt väristades, diivani ees ja tagaajamine jätkub.

Kui Saara väga ära tüdineb, hüppab ta aknalauale ja vaatab sealt Joosepi tegemisi. Siis on Joosepil kisa lahti, sest keegi peab ta aknalaua juurde upitama. Aga ega Saara ootama jää. Kui Joosep kellegi süles talle ja aknalauale läheneb, on kass sealt kadunud ja poisil kisa taas lahti.

Eriti meeldib Joosepile vanaisa süles olles kiisut taga ajada. Kass kiirendab sellisel juhul sammu, vanaisa ka ja poiss rõkkab rõõmust, kui mööda tuba edasi-tagasi tormatakse.

Ühelegi kassile ei meeldi, kui teda sabast sikutatakse. Ega see Saaralegi meeldi. Ometi meeldib kõikidele lastele teatud vanuseni kassi sabast sikutada. On ju kassi saba kui kruusisang või harjavars, millest on hea kinni 
võtta. Joosep sikutab kassi mitu korda päevas. Talle öeldakse, et ära sikuta, kassil on valus, aga ometi ei jäta poiss juhust kasutamata, et sabast kinni haarata, kui kass tema eest tugitooli taha varjub ja oma vonkleva saba välja unustab. See lihtsalt kutsub sikutama. Kass kräunub siis valust või solvumisest ning paneb kõik majaelanikud jooksma, et kiisut Joosepi käest päästa.

Saaral on võimalus poissi hammustada või käpaga lüüa, aga ta ei tee seda kunagi. Ootab hoopis kräunudes, millal ta ülekohtuse kiusaja käest vabastatakse.

Võib arvata, et kass, keda niimoodi kiusatakse, peaks oma kiusajast eemale hoidma. Tegelik olukord on vastupidine. Saara istub Joosepi mänguasjade keskel nagu oodates, millal poiss jälle temaga tegeleb. Samuti kõnnib ta siis Joosepil sabas, kui poiss tema sabas ei kõnni. Nii et tekkinud on uus sõpruskond.

Muidugi on poisiga maadlemine kiisut õpetanud, et kräunuda tuleb enne, kui haiget saad, siis tullakse varem appi ja võib-olla jõutakse enne kohale, kui sa üldse haiget saad. Selle näiteks võib tuua juhuse, mil ma võtsin Saara selja tagant sülle. Ta lasi algul kuuldavale appikarje, aga nägi siis, et tõstja olen mina ja jäi vait.

Kasside paaritumine, nagu teada, toimub veebruaris-märtsis. Sellega kaasnevad isaste võitlused ja metsikud karjed. Kõikidele maaelanikele on teada sõna "kassipulm". Siis kogunevad kõik ümbruskonna isased saadaval oleva emase pärast võitlema. Pojad sünnivad aprillis-mais.

Saara oli saanud jaanuaris tiinestumisvastase süsti. Seega läks veebruari-märtsi indlemisaeg mööda. Järelindlemine on kassidel juunis. Saarale anti küll tablette, aga arvatavasti eraldas ta õhku ikka mingisuguseid feromoone. Igatahes kogunesid isased kõutsid ümber maja. Saara piilus neid nagu häbelik lossipreili läbi erinevate akende ja ukseklaaside. Mõnel hommikul, kui ma tööle läksin, oli neli kõutsi maja ümbruses koha sisse võtnud. Kaks neist olid naabermajade kassid, teised kusagilt kaugemalt. Nende hulgas oli näha ka musta hiiglast.

Eriti jultunud oli mustavalge kasukaga noor naabrikass, kes praokil uksest majja tuli ja Saarat jälitas. Andres oli ülemisel korrusel ja tuli lärmi peale vaatama, mis lahti. Naabrikass pani siis jooksu, aga natukese aja pärast oli ta tagasi. Kui uks oli kinni pandud, jäi ta ukseklaasi taha passima. Siis tekkis huvitav moment, kui isane väljas meelitavalt näugus ja Saara koridoris tema peale urises.

Nüüd on Saara päev läbi inimestega koos ja suhtlusest küllastunud. Kui ma õhtul töölt tulen, ei tegele ta minuga eriti. Tema põhiliseks sõbraks on väikene Joosep. 


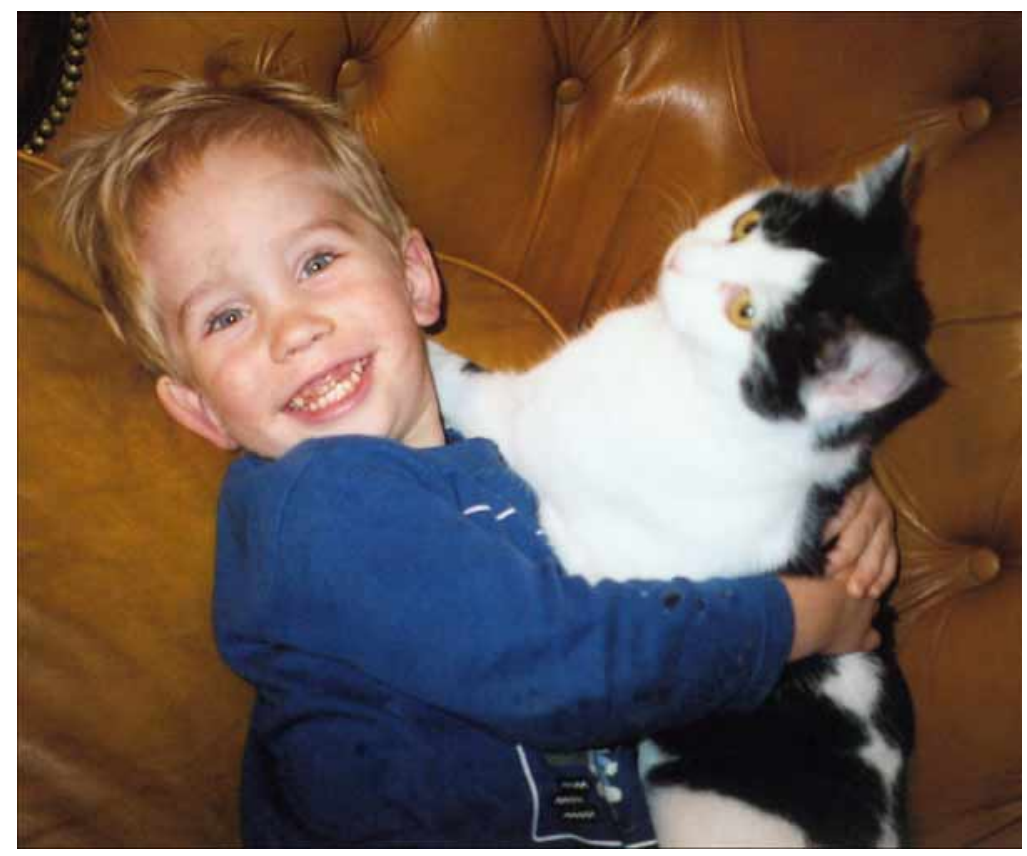

Foto 4. Ema ja poeg. Ülo Siimetsa foto 2006.

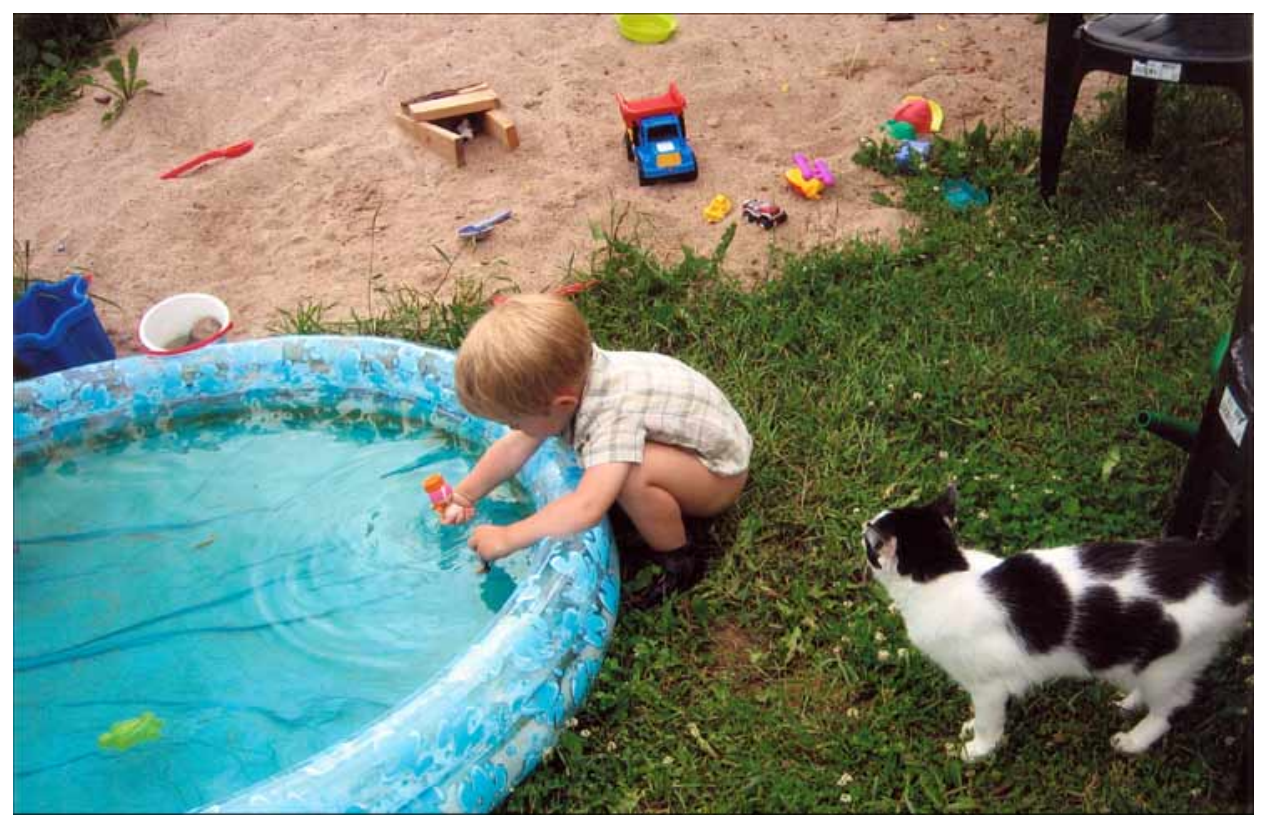

Foto 5. Joosep ja Saara basseini juures. Ülo Siimetsa foto 2006. 
Mida ma õppisin kassikarjas olles?

Esiteks sain kinnitust sellele, et kassid võivad olla väga kättemaksuhimulised. Kui sa looma võtad, pead temaga ka tegelema. Kindlasti on kassid erinevad ja kui sa neile halba teed, teeb kass sulle selle tagasi.

Sain ka selgeks, et Saara armastab seltskonda ja vahelduvat toitu. Ühte toitu ei tohi talle kogu aeg anda, sest siis jätab ta liiga palju sööki järele. Ka tuleb talle anda toitu ette vähem, aga tihedamini - siis on kauss alati tühi ja puhas. Kui ta kogu toitu ära ei söö, pead koputama näpuga vastu kaussi ja ütlema: "Söö, söö, söö!" Selle tegevuse peale tuleb ta tagasi kausi juurde ja sööb edasi.

Kassitoitudest meeldisid talle kiles Whiskasi ja Kitekati road (tuunikala, kalkun ja küülik jne).

Sheba metalltopsides konservid talle ei meeldinud. Kuigi Saara armastab krõbistada krevette, sõi ta krevetikonservi ainult esimesel päeval. Hiljem ta seda konservi ei puutunud. Ega see konserv ka minu arvates just kõige parema lõhnaga olnud. Seetõttu olin sunnitud pool karbitäit naabrikoertele viima. Need sõid isukalt, anna ainult rohkem ette.

Kõige isukamalt sõi Saara siis, kui andsin talle järjekorras erinevaid konserve. Näiteks hommikul osa Whiskasi lihakonservipakist, järgmistel kordadel natukene tuunikalakonservi, siis Juniori, siis Adulti jne, kuni ring jälle täis sai. Vahelduseks sai talle antud ka suitsutatud hõbeheigi- või tursanahka, aga neid sõi ta ainult korra ja siis ei hoolinud nendest tükk aega. Kalaliha sõi ta muidugi parema meelega kui nahka, eriti suitsutatud siiga. Kõige paremini maitses talle metskitse- ja põdrapraad, aga paraku maitseb see mulle endale ka.

Ühesõnaga, kassi haistmine on terav ja ta saab lõhnast aru, milline toit on kvaliteetne, milline mitte. Keeduvorstiga ei tasu õiget kassi narrima minnagi. Seda ta ainult nuusutab ja jätab vedelema. Korralikku sinki või suitsuvorsti ta siiski sööb.

Saara on kassikempsus harjunud Kittyfriendi puruga. Kui kasutasin vahepeal teistsugust kassiliiva, oli selle lõhn talle võõras ja harjumatu ning kiisu käis mitmeid tiire ümber kempsu, nuusutas, käis jälle jne, enne kui oma häda lõpuks ära tegi.

Mida aga arvata kääbusküülikutest? Mina isiklikult arvan, et kui sa tahad kellelegi vingerpussi mängida, kingi tema lapsele isane küülik. Loom võib olla küll ilus, aga tema lõhn ei ole tihtilugu kõige parem. 


\section{Kirjandus}

Otten, Reinhard Ferdinand Ewald. Album Dorpato-Livonorum: Als Manuskript gedruckt. Dorpat 1908.

\section{Summary}

\section{Just another cat}

\section{Ülo Siimets}

It is a tale about a street cat called Saara, who was adopted by the family of the author. The story relates how the cat adapted with the family and another pet in the family - the rabbit; how it raised and protected its offspring. The author describes the extremely varying relationships between the cat and the people who took care of it, ranging from great friendship with family members, especially children, to the "stinking" war of revenge declared to temporary tenants, with "accidents" in bed and on clothes, faeces in the house, and scratches on furniture. 